\title{
The sound aesthetic of servicescape: influence in the aesthetic experience of employees
}

\author{
Humberto Costa ${ }^{1}$, Trajano F. B. X. Silva ${ }^{2}$
}

${ }^{1}$ Faculty of Engineering, University of Porto, PT, (humbertoccosta@gmail.com) ORCID 0000-0003-0329-9004, 2Faculty of Engineering, University of Porto, PT, (up201802228@fe.up.pt) ORCID: 0000-0001-7168-4161 https://doi.org/10.24840/978-972-752-260-6_0110-0114

\begin{abstract}
Introduction: This research deals with the influence of the soundscape of the servicescape along to collaborators, according to the service design perspective. It is understood that Service Design (SD) covers the design of the entire service experience, as well as the design of the process and the strategies for delivering it. Some elements that are included in this process include the provider, developers, servicescape, products, clients, etc. The central point of the SD is to understand the value and nature of relationships between people and people, between people and things, between people and organizations, and between organizations of various kinds. In the scope of SD, the Aesthetic dimension assumes a higher level of complexity, since the relational aspects between human beings (employees and clients) are added, elements that often determine the quality of the experience of service as a whole. In order for the customer to receive an excellent service, it is essential to pay attention to the condition of the employees who provide the service. In this respect, an aesthetic approach has the potential to diagnose and enable innovative solutions to be better explored. The problem was questioned: how does sound aesthetics influence the aesthetic experience of collaborators in servicescape? The objective was to demonstrate how sound aesthetics influence the aesthetic experience of employees in a servicescape. Methodology: To answer the research question, a bibliographic review was carried out, and a survey was undertaken in a shopping mall in the city of Curitiba / Brazil. The RPEAudição tool was used to collect the data. The survey counted on the participation of employees who work in the servicescape of the company that provides the service. Results and Discussion: The results showed that the soundscape of servicescape influences the creation and maintenance of the mood state and can directly impact the health of the employees. The soundscape of the analyzed servicescape evokes positive emotions in the collaborators. In a servicescape focused on hedonic consumption, it is essential that positive emotions are evoked and reinforced, as they can create or reinforce positive moods as well. Such a scenario can bring better working conditions to employees, impact on the quality of life, health, potentiate consumption and interfere in the creation of a positive image about the establishment. Conclusions: As a suggestion for future work, it is recommended to conduct research involving other hedonic service environments in order to deepen the knowledge about the influence of the sound landscape on the aesthetic experience of the collaborators.
\end{abstract}

Keywords: Sound aesthetics, Aesthetic Experience, Servicescape, Service Design, Sound Landscape.

\section{INTRODUCTION}

The services sector generates the largest share of Gross Domestic Product (GDP) of the world's largest economies (Costa, 2017). The services have required the generation of specific knowledge in the field of Design (Mager, 2004) and there is also the collaborators' conditions. Aesthetics permeates all human activity, and any phenomenon has the potential to evoke aesthetic responses (Hekkert \& Leder, 2008). The importance of the study of Aesthetics is greater in sectors where the aesthetic experience of people impacts on their satisfaction with the service received (Costa, 2017). This is the case of services that are provided, for example, by shopping malls. In order for the customer to receive an excellent service, it is essential to pay attention to the condition of the employees who provide the service. The question that guided this research was: How does sound aesthetics influence the aesthetic experience of employees in a given servicescape? The objective was to demonstrate how sound aesthetics influence the aesthetic experience of employees in a particular servicescape. Services refer to a provision of something that someone performs for the utility, satisfaction, or support of another person's activity (Pacenti, 2006). The service offering is based on the provision of these actions and experiences and have the purpose of delivering the benefits to someone. The value of services to people is always a combination of functional elements and emotional elements. Because it 
belongs to the domain of sense construction, services can be linked to Design (Freire, 2011). It is understood that Service Design (SD) covers the design of the entire service experience, as well as the design of the process and the strategies for delivering it (Costa, 2017). Some elements that are included in this process include the provider, developers, servicescape, products, costumers, etc. The central point of the SD is to understand the value and nature of relationships between people and people, between people and things, between people and organizations, and between organizations of different kinds (Costa, 2017). According to the Greek sense, Aesthetics denotes sensation, feeling, esthesis (Rosenfield, 2009). It is Aesthetics's task to analyze the complex of human emotions and feelings by investigating "(...) their integration into the physical and mental activities of man, focusing on the productions (artistic or otherwise) of sensibility, in order to determine their relations with knowledge, reason and ethics "(Rosenfield, 2009, p.7). However, for the purposes of SD, Aesthetics must be approached by a broader meaning, that is, as an integrative experience of sensory, behavioral and reflexive perception experienced by an individual. This means that Aesthetics involves a type of human experience that begins with the sensory perception of a phenomenon (sensory level), which transforms the body landscape (behavioral level) and culminates in meaning about all the experience experienced (reflective level) (Costa, 2017). In the scope of SD, the Aesthetic dimension assumes a higher level of complexity, since the relational aspects between human beings (employees and clients) are added, elements that often determine the quality of the experience of service as a whole. One of the components of the spectrum of shades of the human sensory system consists of sounds (Schafer, 2011). Human beings use sounds not only to communicate but also to interpret and express their aesthetic perception in relation to the world around them (Schafer, 2011). Sounds are able to influence affective aspects, evoking emotions and feelings (Ackerman, 1992). Sounds have the potential to induce the listener to make decisions or influence their behavior. The diversity of sounds present in a given environment forms a "sound landscape" (Schafer, 2011). What characterizes the composition of a particular sound landscape is the presence of environmental sounds in recognizable contexts (Truax, 1996). Among the possible and often present sounds along the journey through the service is the music. Physical evidence constitutes the service environment (the servicescape). This is where the service is provided and where users and collaborators interact (Zeithaml et al., 2014). Included in the servicescape concept are all exterior attributes such as signage, parking, and landscaping, etc. As for the interior attributes, these are composed by space layout, equipment, developers, decoration, sounds, courtesy, care, empathy, etc. In relation to human behaviors in servicescape, it is known that the human being is influenced by the physical facilities. In these cases, people respond in two ways: approach and avoidance (Bitner, 1992). Approach behaviors are those related to the desire to stay, to explore, to return to the establishment, etc. On the other hand, avoidance behaviors are the opposite. The elements perceived in the service environment have the potential to induce aesthetic responses, which can influence behaviors. The qualities of the environments are of two dimensions: pleasure / displeasure and degree of enthusiasm (Bitner, 1992). Stimulating environments are viewed positively, unless enthusiasm is combined with something unpleasant, such as excessive noise, which may be avoided by some people (Zeithaml et al., 2014).

\section{METHODOLOGY}

This research presents a qualitative and exploratory approach (Gray, 2012). As for the procedures, the bibliographic review was used and a survey was carried out with the purpose of raising information directly with a group of interest, regarding the data that one wanted to 
obtain. First, a Assistamatic Bibliographic Review, RBA, (Creswell \& Clark, 2013; Webster \& Watson, 2002) on the themes of service design, aesthetics, aesthetic experience, services aesthetics, servicescape, sound aesthetics and sound landscape to allow greater understanding of the main terms and authors. As an initial source for the RBA, a search was made for articles published between 2010 and 2017 in the Web of Science and Ebsco Host databases, with the purpose of analyzing the density and the evolution of the research on the themes pertinent to this work. The search strings adopted were: "service design"; "Aesthetics"; "Aesthetic experience"; "Servicescape"; "Sound aesthetics" and "sound landscape". Survey research is a useful procedure in exploratory research, in which data are sought on the opinions and characteristics of a particular group of people (Gray, 2012). For the collection of data, the "Wheel of Aesthetic Perception - Audition", RPE-Audição (Costa, 2017) was used and the guidelines for the application of the instruments and for the analysis of the data were followed. The survey was conducted in the premises of Shopping Curitiba and the target audience were employees who worked in the mall. Respondents were chosen randomly, regardless of gender.

\section{DATA ANALYSIS AND INTERPRETATION OF RESULTS}

On May 6, 2017, a survey was carried out in the premises of Shopping Curitiba, with the application of the "Wheel of Aesthetic Perception - Audition", with the purpose of collecting data about the visceral aesthetic perception evoked by the sound landscape in the collaborators. Two interviewers approached 25 employees who were distributed throughout the four floors of the establishment. It was observed that in the services of Shopping Curitiba, there are initiatives to create a "sound landscape" with the purpose of awakening and reinforcing positive moods in people, with direct contributions in their journey through the service. In general, it can be said that the sound landscape of the analyzed service environment is, from the auditory point of view, not very noisy. Table 1 shows the frequency and intensity of the emotions that are evoked in the employees from the sound landscape present in the analyzed servicescape. The table also shows the frequency and intensity with which each of the emotions is expected in the same servicescape. According to Table 1 , it is noted that there is a predominance of positive emotions evoked in the collaborators. The aesthetic experience of the collaborators, in the midst of 10 most experienced emotions is based on eight positive emotions, which have high gradations (4, 5 or 6 ). On average, $23 \%$ of the respondents said they experienced emotions such as tranquility, Enthusiastic, happiness, fun and serenity in high gradations $(4,5$ or 6$)$. This points to a positive aesthetic experience. In a service environment focused on hedonic consumption, it is crucial that positive emotions are evoked. Positive emotions are fundamental to the creation and / or reinforcement of positive mood states. Creating and reinforcing positive moods provides a positive experience for people as well. This will contribute to a better service delivery by the employees, which has the potential to contribute to the construction of a positive image about the establishment with the customers. Moreover, it is inferred that positive moods have the potential to lead the user to consume, which would be very interesting for the establishment. In a city with several establishments focused on hedonic consumption, it is inferred that those who provide a better experience to users will be those with higher possibility of attracting even more consumers. 
Table 1. Gradation of felt and expected emotions in servicescape Shopping Curitiba, according to the aesthetic perception evoked by hearing

\begin{tabular}{|c|c|c|c|c|c|c|c|c|c|}
\hline \multirow[b]{2}{*}{ Emotion (Hearing) } & \multirow[b]{2}{*}{$\begin{array}{c}\text { Gradation } \\
\text { Felt }\end{array}$} & \multirow[b]{2}{*}{$\begin{array}{c}\text { Expected } \\
\text { Graduationn }\end{array}$} & \multicolumn{6}{|c|}{ Indicated Degree } & \multirow[b]{2}{*}{6} \\
\hline & & & 0 & 1 & 2 & 3 & 4 & 5 & \\
\hline Happy & 196 & 244 & 109 & 0 & 1 & 5 & 9 & 13 & 13 \\
\hline Excited & 79 & 148 & 133 & 1 & 0 & 0 & 5 & 8 & 3 \\
\hline Enthusiastic & 209 & 170 & 105 & 1 & 1 & 2 & 16 & 14 & 11 \\
\hline Serene & 104 & 126 & 127 & 3 & 1 & 0 & 3 & 9 & 7 \\
\hline Fun & 117 & 181 & 123 & 0 & 3 & 2 & 11 & 5 & 6 \\
\hline Tranquility & 284 & 281 & 88 & 1 & 3 & 3 & 22 & 18 & 15 \\
\hline Admired & 38 & 82 & 140 & 1 & 2 & 1 & 3 & 0 & 3 \\
\hline Affectionate & 53 & 22 & 139 & 0 & 0 & 1 & 4 & 2 & 4 \\
\hline Stimulated & 74 & 71 & 134 & 0 & 0 & 4 & 2 & 6 & 4 \\
\hline Inspired & 77 & 143 & 133 & 0 & 1 & 1 & 5 & 8 & 2 \\
\hline Meditative & 27 & 12 & 142 & 1 & 0 & 3 & 3 & 1 & 0 \\
\hline Melancholic & 25 & 3 & 142 & 1 & 1 & 3 & 2 & 1 & 0 \\
\hline Nervous & 53 & 1 & 135 & 3 & 2 & 2 & 2 & 4 & 2 \\
\hline Sentimental & 32 & 31 & 142 & 1 & 0 & 1 & 4 & 0 & 2 \\
\hline Affected & 6 & 3 & 146 & 2 & 2 & 0 & 0 & 0 & 0 \\
\hline Impatient & 81 & 4 & 127 & 1 & 3 & 8 & 8 & 0 & 3 \\
\hline Nostalgic & 40 & 45 & 140 & 0 & 2 & 2 & 2 & 2 & 2 \\
\hline Horrified & 8 & 1 & 145 & 2 & 3 & 0 & 0 & 0 & 0 \\
\hline Saddened & 4 & 1 & 147 & 2 & 1 & 0 & 0 & 0 & 0 \\
\hline Tense & 76 & 5 & 131 & 3 & 1 & 0 & 7 & 5 & 3 \\
\hline
\end{tabular}

On the other hand, it can be observed in Table 1 that negative emotions were also evoked in the collaborators by the soundscape of the servicescape analyzed. Emotions like impatience and tension were the most experienced. When it comes to collaborators, the presence of such emotions is worrying. Based on the servicescape analyzed, negative emotions should be at a level far below what was found. This assertion stems from an inference that a negative aesthetic panorama contributes to the generation / reinforcement of negative mood states as well. People with negative moods tend to retract and avoid any kind of approach, impacting the quality of the service provided. When it comes to consumption, such behavior is not desired. It was possible to verify that the respondents, although they had a positive experience, they wish that such experience is even more positive. For example, in Table 1, it can be seen that the collaborators want the experience evoked by the sound landscape to be even more calm, happy, fun, lively and serene. On the other hand, they want the negative aesthetic panorama to be minimized. For example, they want to feel less impatience, tension, nervousness, melancholy, etc. It was possible to verify that the respondents, although they had a positive experience, they wish that such experience is even more positive. For example, in Table 1, it can be seen that the collaborators want the experience evoked by the sound landscape to be even more calm, happy, fun, lively and serene. On the other hand, they want the negative aesthetic panorama to be minimized. For example, they want to feel less impatience, tension, nervousness, melancholy, etc.

\section{FINAL CONSIDERATIONS}

It was found that the soundscape of a servicescape influences the aesthetic experience of the collaborators. In the case of auditory aesthetic perception, the non-tangible elements that make up the sound landscape are responsible for evoking emotions and feelings that can create or reinforce positive or negative mood states. The soundscape of the analyzed servicescape evokes positive emotions in the collaborators. In a servicescape focused on hedonic consumption, it is 
important that positive emotions are evoked and reinforced, as they can create or reinforce positive moods as well. Such a scenario can bring better working conditions to employees, impact on the quality of life, health, potentiate consumption and interfere in the creation of a positive image about the establishment. The survey also found that the soundscape of servicescape evokes negative emotions, but in the case analyzed, in low proportions. Such a scenario is worrisome since a negative aesthetic panorama contributes to the generation or reinforcement of negative mood states. From this perspective, both employees and users tend to retract and avoid any kind of approach. When it comes to consumption, such behavior is not desired. The research also showed that employees, although they have experienced a positive aesthetic experience, expect it to be even more positive and that aesthetically negative emotions are drastically minimized. Based on this research and from the point of view of SD, it is suggested that the administration of Shopping Curitiba deepen the knowledge about employees and, based on these data, develop aesthetic guidelines to guide future solutions to improve their aesthetic experience. Another suggestion would be the involvement of employees and users in the creation of solutions to improve the aesthetic experience experienced in servicescape. Knowing the desires of employees and service users, it requires understanding their individual experiences with the service, as well as the broader context of their particularities. By knowing and understanding culture, habits, motivations and social context, as well as engaging them deeply in the exploration and definition of service improvement solutions, there is a greater possibility of creating services with high added value that will hardly be copied by the competition. As a suggestion for future work, it is recommended to carry out research involving other service environments in order to deepen the knowledge about the possible influences of the sound landscape on the aesthetic experience of the collaborators who provide the service.

\section{References}

Ackerman, D. (1992). Uma Historia Natural dos Sentidos. São Paulo: Bertrand.

Bitner, M. J. (1992). Servicescapes: The Impact of Physical Surroundings on Customers and Employees. Journal of Marketing, 56(2), 57-71. https://doi.org/10.1177/002224299205600205

Costa, H. (2017). Design para Serviços e Consistência Estética: proposição de um protocolo de avaliação estética em serviços. Universidade Federal do Paraná.

Creswell, J. W., \& Clark, V. L. P. (2013). Pesquisa de Métodos (2nd ed.). Porto Alegre: Penso.

Freire, K. de M. (2011). Design de Serviços, Comunicação e Inovação Social. Pontifícia Universidade Católica do Rio de Janeiro.

Gray, D. E. (2012). Pesquisa no Mundo Real (2nd ed.). Porto Alegre: Penso.

Hekkert, P., \& Leder, H. (2008). Product aesthetics. In H. N. J. Schifferstein \& P. Hekkert (Eds.), Product experience (pp. 259-285). San Diego: Elsevier.

Mager, B. (2004). Service Design: A Review. Köln: Köln Internat. School of Design.

Pacenti, E. (2006). Design dei servizi. In Design multiverso: appunti di fenomenologia del design (p. 252). Milano: POLI.design.

Rosenfield, K. H. (2009). Estética. Rio de Janeiro: Jorge Zahar.

Schafer, M. R. (2011). O Ouvido Pensante. São Paulo: Ed. UNESP.

Truax, B. (1996). Soundscape, Acoustic Communication and Environmental Sound Composition. Contemporary Music Review, 15(1-2), 49-65. https://doi.org/10.1080/07494469608629688

Webster, J., \& Watson, R. T. (2002). Analyzing the Past To Prepare R the Future : Writing a. MIS Quarterley, 26(2), xiiixxiii. Retrieved from https://www.jstor.org/stable/4132319

Zeithaml, V. A., Bitner, M. J., \& Gremler, D. D. (2014). Marketing de serviços : a empresa com foco no cliente (6th ed.). Porto Alegre: Bookman. 